\title{
Molecular pathological changes induced by ultraviolet light during the development of skin cancer
}

\author{
Masato Ueda', Mpu Kanoko ${ }^{2}$, Santoso Cornain ${ }^{2}$, Mochtar Hamzah ${ }^{3}$, Evert Poetiray ${ }^{4}$, Joedo Prihartono ${ }^{5}$, Yoshiyuki
} $\mathrm{Ohno}^{6}$, Masamitsu Ichihashi'

\begin{abstract}
Abstrak
Sinar ultraviolet (uv) merupakan penyebab utama kanker kulit pada manusia. Sinar uv berperan dalam karsionegenesis melalui pengaruh-pengaruh langsung pada sel sasaran dan pengaruh-pengaruh tidak langsung pada tuan rumah (menyebabkan imunosupresi). Penelitian-penelitian akhir-akhir ini telah mulai mengungkapkan berbagai mekanisme molekuler yang terlibat. Pada nakalah ini, kami akan membahas penemuan-penemuan terakhir dan perkembangan di dalam biologi molekuler dari pengaruh sinar uv dalam karsinogenesis pada kulit, dengan perhatian khusus pada kerusakan DNA dan perbaikan DNA, gen penekan tumor p53, apoptosis, gen patched, dan aktivitas telomerasa.
\end{abstract}

\begin{abstract}
Ultraviolet light $(U V)$ is the most important cause of human skin cancers. UV results in carcinogenesis through direct effects on the target cell and indirect effects on the host (immunosuppression). Recent studies have begun to uncover the molecular mechanisms involved. Here, we discuss recent findings and developments in the molecular biology of UV-carcinogenesis in the skin, by focusing on DNA damage and DNA repair, the 53 tumor suppressor gene, apoptosis, the patched gene and telomerase activity.
\end{abstract}

Keywords: ultraviolet light, carcinogenesis, skin cancer, DNA repair, p53, patched gene, telomerase

Although several environmental and genetic factors contribute to the development of skin cancers, the most important is chronic exposure to ultraviolet (UV) light radiation in sunlight. UV has dual actions which elicit the development of skin cancers. First, UV radiation causes DNA damage that results in mutations in cellular genes important for oncogenesis. Second, UV radiation induces immunosuppression that prevents tumor rejection by the host. In this review, recent developments in molecular biology relative to $\mathrm{UV}$-induced skin carcinogenesis are discussed.

'Department of Dermatology, Kobe University School of Medicine, Kobe 650-0017, Japan

${ }^{2}$ Department of Anatomic Pathology, Faculty of Medicine University of Indonesia, Jakarta 10430, Indonesia

${ }^{3}$ Department of Dermatology, Faculty of Medicine University of Indonesia, Jakarta 10430, Indonesia

${ }^{4}$ Department of Surgery, Faculty of Medicine University of Indonesia, Jakarta 10430, Indonesia

${ }^{5}$ Department of Community Medicine, Faculty of Medicine University of Indonesia, Jakarta J0320, Indonesia

${ }^{\circ}$ Department of Preventive Medicine, Nagoya University School of Medicine, Nagoya 466-8550, Japan

\section{DNA damage and DNA repair in UV carcinogenesis}

UV radiation induces chemical alterations in cellular DNA, known collectively as DNA photoproducts. The major photoproducts induced by carcinogenic UVB are cyclobutane pyrimidine dimers (CPD) and (6-4) photoproducts. Both types of these photoproducts are formed at dipyrimidine sites in DNA. Evidence for the role of photoproduct-induced mutagenicity in nonmelanoma skin cancers was provided by a study ${ }^{\prime}$ that showed a high frequency of mutations in the p53 tumor suppressor gene at dipyrimidine sites. These photoproducts are usually repaired by DNA nucleotide excision repair (NER) in normal cells. However, patients with xeroderma pigmentosum (XP) are very sensitive to sun exposure and have an extremely high risk of developing skin cancer. XP cells have defects in NER because XP genes encode proteins important for that process. More recent reports suggest that DNA repair may also be defective in normal individuals who have early onset of basal cell carcinoma $(\mathrm{BCC}){ }^{2}$ Taken together, DNA repair is crucial for protection against UV-induced skin cancer. In one study, T4 endonuclease V (T4N5), which 
specifically repairs CPD, was encapsulated in liposomes which were applied with repeated UVB exposure to hairless mice. Mice treated with T4N5 liposomes had significantly fewer timors than controls, suggesting the importance of CPD in UV carcinogenesis and further suggesting the possibility of using T4N5 liposomes to prevent skin cancer development in human skin. In fact, treatment of skin from XP patients with T4N5 liposomes induced fewer CPD and less erythema than controls. ${ }^{4}$

In addition to reducing the efficiency of repairing DNA photoproducts, higher yields of DNA photoproducts may be associated with increased sensitivity to UV carcinogenesis. In a study ${ }^{5}$ examining human skin irradiated with UVB, yields of CPD and (6-4) photoproducts after the same dose of irradiation were higher in UV-sensitive individuals with low minimal erythema dose than in less sensitive individuals with high minimal erythema dose. That study suggested that DNA photoproducts participate in initiating UVB-induced erythema, which partially explains why individuals with a higher sensitivity to UVB have a higher risk of UV-induced skin cancer.

In contrast to CPD or (6-4) photoproducts, which are formed by the direct absorption of UV energy to DNA, UV also has indirect effects on DNA through the generation of reactive oxygen species in conditions of UV stress. 8-Hydroxy-2-deoxyguanosine (8-OHdG) is a representative DNA base-modified product generated by reactive oxygen species, however, at this time little is known about the role of 8-OHdG in UVinduced human skin carcinogenesis. The formation of 8-OHdG, as well as CPD and (6-4) photoproducts, was examined by immunohistochemistry in human skin after UVB irradiation. ${ }^{6}$ Increased levels of 8OHdG were clearly observed in the epidermis after UVB irradiation, and these were rapidly removed from nuclei during the first $24-48 \mathrm{~h}$, as the staining intensity diminished gradually, almost reaching the control level within $72-96 \mathrm{~h}$ after irradiation. Staining for CPD or (6-4) photoproducts revealed the induction of these photoproducts in human skin, although (6-4) photoproduct-positive cells disappeared more rapidly than those containing CPD or 8-OHdG 8-OHdG induces $\mathrm{GC}$ to $\mathrm{TA}$ transversions during DNA replication. Taken together with the demonstration of GC to TA transversions in the p53 and ras genes in UVB-induced skin cancers in mice and in humans, and the protective effects of antioxidants, these results indicate that not only CPD and (6-4) photoproducts but also $8-\mathrm{OHdG}$ may play significant roles in UV carcinogenesis.

\section{p53 tumor suppressor gene in UV carcinogenesis}

The p53 tumor suppressor gene is involved in various critical cellular functions including cell cycle controi, transcription of other genes, DNA repair, and apoptosis of cells with sustained DNA damage. Mutations in the p53 gene are found in nearly $50 \%$ of all human cancers. This protein plays a pivotal role in the response to DNA damage, including that induced by UV exposure, because it accumulates in the nuclei of damaged cells and causes a delay in the cell cycle at G1 that provides time for DNA repair or elimination of cells by apoptosis. ${ }^{7}$ Mutations of the p53 gene have been found in more than $90 \%$ of human cutaneous squamous cell carcinomas (SCC) and in about $50 \%$ of human BCC. These mutations were predominantly $\mathrm{C}$ to $\mathrm{T}$ or $\mathrm{CC}$ to $\mathrm{TT}$ transitions, implicating UVB-induced CPD and (6-4) photoproducts as the causative mutagens. Premalignant lesions, such as actinic keratosis and Bowen's disease, also showed mutations of the p53 gene Furthermore, mutated p53 genes could be detected in sun-exposed normal skin. By using the allele-specific PCR method to detect CC to TT mutations at codon $247 / 248$ of the p53 gene, one mutant allele in about one million wild-type alleles could be detected. More p53 mutations were detected in Japanese skin samples taken from sites that were chronically exposed to the sun than in those from covered sites. A significant trend of increased p53 mutation frequency with increase in age of subjects was found, suggesting the cumulative nature of these mutations. The p53 mutation frequency was higher in patients with premalignant tumors or non-melanoma skin cancers than in patients with only benign tumors. The sum of these findings support the notion that genetic events leading to cancer occur long before tumor formation and that $\mathrm{p} 53$ gene mutations are early genetic events.

\section{Apoptosis and UV carcinogenesis}

Apoptosis plays an important role as a defense mechanism in eliminating damaged cells. Among the complex factors which regulate apoptosis, $\mathrm{p} 53$ protein induction by DNA damage plays a crucial part. To examine the relationships between DNA damage, $\mathrm{p} 53$ and apoptosis, normal and XP group A fibroblasts were exposed to UVB, and the expression of 
molecules involved in apoptosis was examined. ${ }^{9}$ Apoptosis of XP and normal cells was detected after irradiation with UVB at doses of 5 and $40 \mathrm{~mJ} / \mathrm{cm} 2$, respectively. p53 protein expression was induced in normal and XP cells at minimal doses of 10 and 2.5 $\mathrm{mJ} / \mathrm{cm} 2$, respectively. Bcl-2 protein, an inhibitor of apoptosis, was down-regulated prior to cell death following UVB exposure at doses that induced apoptosis in both cell types. These results suggest that DNA damage induces apoptosis by up-regulating proapoptotic molecules such as $\mathrm{p} 53$, and by downregulating anti-apoptotic molecules such as Bcl-2. It further suggests that loss of $\mathrm{p} 53$ function and/or gain of $\mathrm{Bcl}-2$ function would induce failure of apoptosis, and would lead to carcinogenesis. In fact, the important role of $\mathrm{p} 53$, in the induction of apoptosis in UVB irradiated epidermis was shown by a study using p53 gene knockout mice. ${ }^{10}$ Apoptotic cells (called sunburn cells in the skin) are virtually absent in UVexpused skin of mice with a homozygous knockout of the p53 gene (p53-/-), while heterozygous p53 knockout mice (p53+/-) have a partially reduced response in comparison to normal wild-type (p53+/+) mice. In $\mathrm{p} 53-\%$ mice, SCC are easily induced following exposure to UV. Fas-Fas ligand (Fas L) interaction is also crucial for induction of apoptosis and prevention of UV-carcinogenesis. Sunburn cell formation after UVB in Fas L gene knockout mice was shown to be reduced. In addition, chronic exposure to UV caused p53 mutations in the epidermis detected by allele-specific PCR in 14 of 20 Fas L-deficient mice and in only 1 of 20 wild-type mice. ${ }^{11}$ These results clearly show that failure of apoptosis facilitates the accumulation of genetic alterations which lead to carcinogenesis.

\section{Patched gene in carcinogenesis}

The human homologue of the Drosophila segment polarity gene patched (PTCH) has been associated with the nevoid BCC syndrome and has been shown to be mutated in sporadic BCC. The PTCH gene maps to chromosome 9q22.3 and encodes a transmembrane glycoprotein that is the receptor for the hedgehog (HH) signaling protein. The PTCH protein receptor plays a central role in regulating the $\mathrm{HH}$ signaling pathway, whose main function is to control cell differentiation and proliferation. CC to TT or C to T mutations at dipyrimidine sites were also found in the PTCH gene in sporadic BCC from XP and non-XP patients, with a higher level of UV-induced mutations in XP BCCs $(79 \%$ vs. $44 \%){ }^{12,}{ }^{13}$ In sporadic skin tumors, PTCH abnormalities are relatively specific to BCC. We examined the expression of PTCH mRNA in various skin tumors, since mutational inactivation of PTCH leads to overexpression of mutant transcripts owing to failure of a negative feedback mechanism. ${ }^{14}$ The expression was high in all 12 BCC examined but not in 23 other skin tumors, including SCC, malignant melanoma (MM), actinic keratosis, Bowen's disease and 4 normal skin samples (with the exception of one specimen of Bowen's disease). Thus, PTCH is now regarded as a gatekeeper gene for the development of BC.C. Smoothened (Smoh) encodes a downstream protein of PTCH in the HH signaling pathway. The Smoh transcript was shown to be specifically overexpressed in BCC. ${ }^{15}$ The transcription factor Glil was also found to be over-expressed in $\mathrm{BCC}$, indicating that activation of the HH-PTCH-Smoh signaling pathway induces Gli1 expression. The target gene of Glil regulation must have a central role in BCC development and the identification of this molecule is a matter for future study.

\section{Telomerase in UV carcinogenesis}

Telomerase is a ribonucleoprotein enzyme (an RNAdependent DNA polymerase) that catalyses the addition of telomeric repeats (TTAGGG)n to telomeres, the distal ends of eukaryotic chromosomes. Telomeres cap chromosome ends and protect the chromosome from instability. The maintenance of telomere length requires telomerase activity since conventional DNA polymerases cannot fully replicate the linear DNA termini. Telomerase is activated in germline cells and in a variety of malignant tumors. In contrast, telomerase activity is usually repressed in normal somatic cells, except in some self-renewing tissues with high regenerative potential, such as hematopoietic cells. Telomerase activation is thus thought to be crucial for the continued growth or progression of cancer cells via the stabilization of telomere length. Telomerase activity has been analyzed in various types of skin tumors. We found that telomerase was activated in 3 of 4 seborrheic keratoses, in 16 of 18 premalignant skin tumors (including 9 actinic keratoses), in 5 Bowen's disease, in $1 \mathrm{MM}$ in situ, in 2 genital Paget's disease, in 1 sebaceous epithelioma, in 11 of $13 \mathrm{BCC}$, in 6 of 6 $\mathrm{SCC}$, in 4 of $5 \mathrm{MM}$, and in 1 of 1 eccrine carcinoma, showing that telomerase is frequently activated in premalignant lesions and in skin cancers including BCC, SCC and MM. ${ }^{16}$ Normal human skin shows a lower frequency of telomerase activity. Taylor et al. ${ }^{17}$ 
and our group ${ }^{16}$ found that telomerase activity was higher in sun-exposed normal skin compared with sun-protected skin, suggesting a UV-associated activation of telomerase in human skin. In our study, $54 \%$ (21 of 39) of normal skin samples from chronically sun-exposed sites were telomerasepositive, compared with only $12 \%$ (3 of 26 ) of samples from covered sites, suggesting that UV light activated telomerase. Considering the fact that solar $\mathrm{UV}$ radiation is a major etiological factor of skin cancer, and that mutations of the p53 tumor suppressor gene frequently occur in early stages of UV-induced skin carcinogenesis, we examined telomerase activity and $\mathrm{CC}$ to TT mutations at codon $247 / 8$ of the p53 gene in these same normal skin samples. Only $43 \%$ (7 of 16 ) of telomerase-positive normal skin samples at sun-exposed sites contained those specific p53 mutations, whereas all (7 of 7) samples with UV-specific p53 mutations showed increased telomerase activity. These data suggest that telomerase activation is involved at an early stage of human skin carcinogenesis and that activation of telomerase may actually precede the acquisition of UV-associated p 53 mutations in the skin. However, as telomerase activity alone is not sufficient for immortalization of human keratinocytes in vitro, the role of telomerase in UV-carcinogenesis in vivo needs to be further characterized. Three major subunits of human telomerase, human telomerase RNA, telomerase-associated protein, and human telomerase catalytic subunit (hTERT), have been identified recently. hTERT expression has been shown to be correlated with telomerase activity. Our study on the expression of these subunits in normal human skin and in skin tumors has also shown a strong correlation between telomerase activity and the expression of hTERT, which indicates that hTERT functions as a critical determinant of telomerase activity in the skin. ${ }^{18}$ The recent identification of the hTERT gene promoter should allow the molecular mechanisms involved in the regulation of hTERT expression by $\mathrm{UV}$ to be characterized in the future.

\section{Acknowledgement}

We are indebted to the International Cancer Research Grant system, Monbusho, Japan and the Dean, Faculty of Medicine, University of Indonesia, Jakarta, for his approval of the Japan-Indonesia collaborative study. This work has been supported by the grant no. 09042004, under Ministry of Education, Science, Sport and Culture, Government of Japan and was partly supported by the Indonesian Cancer Foundation, the Jakarta International Cancer Conference Fund and the Terry Fox Foundation, Canada. The collaborative study was initiated with Dean's approval no. 845/PT02.H4.FK/E/97 and technical support by the Director of Dr. Cipto Mangunkusumo National Central General Hospital.

\section{REFERENCES}

1. Brash DE, Rudolph JA, Simon JA, Lin A, McKénna GJ, Baden HP et al. A role for sunlight in skin cancer: UVinduced p53 mutations in squamous cell carcinoma. Proc Natl Acad Sci USA, 1991; 88: 10124-8.

2. Wei Q, Matanoski GM, Farmer ER, Hedayati MA, Grossman L. DNA repair and aging in basal cell carcinoma: a molectlar epideniology study. Proc Natl Acad Sci USA, 1993; 90: 1614-8.

3. Bito $T$, Ueda $M$, Nagano $T$, Fujii $S$, Ichihashi $M$. Reduction of ultraviolet-induced skin cancer in mice by topical application of DNA excision repair enzymes. Photodermatol Photoimmunol Photomed, 1995; 11: 9-13.

4. Yarosh D, Klein J, Kibitel J, Alas L, O'Connor A, Cummings $B$ et al. Enzyme therapy of xeroderma pigmentosum: safety and efficacy testing of T4N5 liposome lotion containing a prokaryotic DNA reparr enzyme. Photodermatol Photoimmunol Photomed, 1996; 12: 122-30.

5. Ueda $M$, Matsunaga $T$, Bito $T$, Nikaido $O$, Ichihashi $M$. Higher cyclobutane pyrimidine dimer and (6-4) photoproduct yields in epidermis of normal humans with increased sensitivity to ultraviolet B radiation. Photodermatol Photoimmunol Photomed, 1996; 12 :22-6.

6. Ahmed NU, Ueda M, Nikaido O, Osawa T, Ichihashi M. High leveis of 8-hydroxy-2-deoxyguanosine appear in normal human epidermis after a single dose of ultraviolet radiation. Br J Dermatol, 1999; 140: 226-31.

7. Ueda M, Ahmed NU, Bito T, Nagano T, Ichihashi M. The expression of retinoblastoma protein in epidermis is induced by ultraviolet B exposure. $\mathrm{Br}$ J Dermatol, 1996; 135: 406-11.

8. Ouhtit A, Ueda M, Nakazawa $H$, Ichihashi M, Dumaz N, Sarasin A, et al. Quantitative detection of ultravioletspecific p53 mutations in normal skin from Japanese patients. Cancer Epidemiol Biomarkers Prev, 1997; 6: 433-8.

9. Washio F, Ueda M, Ito A, Ichihashi $M$. Higher susceptibility to apoptosis following ultraviolet B irradiation of xeroderma pigmentosum fibroblasts is accompanied by upregulation of $\mathrm{p} 53$ and downregulation of Bcl-2. Br J Dermatol, 1999; 140: 1031-7.

10. Ziegler A, Jonason AS, Leffell DJ, Simon JA, Sharma HW, Kimmelman et al. Sunburn and p53 in the onset of skin cancer. Nature, 1994; 372: 773-6.

11. Hill LL, Ouhtit A, Loughlin SM, Kripke ML, Ananthaswamy HN, Owen-Schaub LB. Fas ligand: A sensor for DNA damage critical in skin cancer etiology. Science, 1999; 285: 898-900. 
12. Gailani MR, Stahle-Backdahl M, Leffell DJ, Glynn M, Zaphiropoulos PG, Pressman C et al. The role of the human homologue of Drosophila patched in sporadic basal cell carcinomas. Nat Genet, 1996; 14: 78-81.

13. Bodak N, Queille S, Avril MF, Bouadjar B, Grougard C, Sarasin A et al. High levels of patched gene mutations in basal-cell carcinomas from patients with xeroderma pigmentosum. Proc Natl Acad Sci USA, 1999; 96:5117-22.

14. Nagano T, Bito T, Kallassy M, Nakazawa H, Ichihashi M, Ueda $M$. Overexpression of the human homologuc of Drosophila patched (PTCH) in skin tumors: specificity for basal cell carcinoma. Br J Dermatol, 1999; 140: 287-90.

15. Kallassy $M$, Toftgard $R$, Ueda $M$, Nakazawa $H$, Vorechovsky I, Yamasaki $\mathrm{H}$ et ai. Patched (ptch)- associated preferential expression of Smoothened (smoh) in human basal cell carcinoma of the skin. Cancer Res, 1997; 57: 4731-5.

16. Ueda $M$, Ouhtit A, Bito $T$, Nakazawa $K$, Lubbe $J$, Ichihashi $\mathrm{M}$ et al. Evidence for UV-associated activation of telomerase in human skin. Cancer Res, 1997; 57:370-4.

17. Taylor RS, Ramrez RD, Ogoshi M, Chaffins M, Piatyszek MA, Shay JW. Detection of telomerase activity in malignant and nonmalignant skin conditions. J Invest Dermatol, 1996; 106: 759-65.

18. Wu A, İchihashi $M$, Ueda $M$. Expression of human telomerase subunits and correlation with telomerase activity in normal skin and skin tumors. Cancer, 1999; 86: 2038-44. 